\title{
Aplikasi Peminjaman Ruangan Rapat Kantor Gubernur Provinsi Kepulauan Bangka Belitung Berbasis Android
}

\author{
Rendy Rian Chrisna Putra ${ }^{[1]}$, Eza Budi Perkasa ${ }^{[2]}$ \\ ${ }^{[1],[2]}$ Program Studi Teknik Informatika \\ STMIK Atma Luhur \\ Jl. Jendral Sudirman, Selindung Baru, Pangkalpinang \\ rendyriancp@atmaluhur.ac.id ${ }^{[1]}$, ezabudiperkasa@atmaluhur.ac.id ${ }^{[2]}$
}

\begin{abstract}
Abstrak-Peminjaman ruangan rapat di Kantor Gubernur Provinsi Kepulauan Bangka Belitung yang dilakukan saat ini masih melalui proses manual yaitu peminjaman harus menemui langsung pihak pengelola yang ada di kantor Gubernur untuk mendapatkan persetujuan peminjaman ruangan yang dibutuhkan. Dengan pemanfaatan teknologi mobile saat ini akan dibangun sebuah aplikasi berbasis Android. Aplikasi yang akan dibangun ini menggunakan bahasa pemrograman java dengan platform pembantu yaitu android studio, PHP, dan database MySQL. Metode yang digunakan pada penelitian ini adalah metode berorientasi objek dan menggunakan alat bantu pemodelan Unified Modelling Language (UML) untuk menggambarkan aplikasi yang dibangun dan menggunakan model Prototype. Hasil pengujian menggunakan blackbox menunjukan bahwa aplikasi peminjaman ruangan ini dapat digunakan oleh pengguna dengan baik serta bisa melakukan peminjaman ruangan dengan aplikasi ini. Dengan adanya aplikasi ini diharapkan dapat membantu pengguna untuk lebih mudah melakukan peminjaman ruangan.
\end{abstract}

Kata Kunci: Aplikasi Mobile, Android, Peminjaman Ruangan

\section{PENDAHULUAN}

Kantor Gubernur Provinsi Kepulauan Bangka Belitung merupakan kantor dinas Gubernur Provinsi Kepulauan Bangka Belitung, Kantor Gubernur tersebut memiliki banyak ruangan rapat yang sering dipinjam untuk digunakan OPD-OPD yang ada di dinas Provinsi Kepulauan Bangka Belitung, Kantor Gubernur Provinsi Kepulauan Bangka Belitung mempunyai unit logistic yang salah satu tugasnya adalah mengelola peminjaman ruang rapat seluruh OPD yang ada di dinas-dinas provinsi dan mengelola perlengkapan di kantor Gubernur Provinsi Kepulauan Bangka Belitung.

Peminjaman ruangan rapat di Kantor Gubernur Provinsi Kepulauan Bangka Belitung yang dilakukan saat ini masih melalui proses manual yaitu peminjaman harus menemui langsung pihak pengelola yang ada di kantor Gubernur untuk mendapatkan persetujuan peminjaman ruangan yang dibutuhkan. Di sisi lain saat ingin meminjam ruangan harus menemui pengelola terkait untuk peminjaman ruangan harus menemui langsung pihak-pihak terkait yang terkadang berhalangan hadir atau sedang tidak ada di tempat. Selain itu, dari peminjaman ruangan yang disetujui dibutuhkan laporan terkait data peminjaman ruangan yang disetujui guna mengetahui ruangan yang sering dipakai sehingga dapat membantu dalam pemeliharan ruangan secara berkala.

Berdasarkan masalah yang dijabarkan diatas, penulis membangun sebuah aplikasi berbasis android, dimana aplikasi itu memiliki fitur untuk pengelola laporan peminjaman ruangan untuk membantu pengelola dalam mengetahui laporan data ruangan sehingga dapat melakukan perbaikan secara berkala, laporan juga dapat dicetak dan atau diunduh oleh pengelola berbasis web.

Ada beberapa penelitian yang relevan dengan penulis lakukan, antara lain Penelitian mengenai "Aplikasi pengelolaan dan peminjaman ruangan di fakultas ilmu terapan, Universitas Telkom"[1]. Penelitian mengenai "Sistem Informasi Peminjaman Barang Fakultas MIPA UNS"[2]. Penelitian mengenai "Pengembangan aplikasi peminjaman ruang subag umum kepegawaian dan perlengkapan (ukp) fmipa universitas negeri Yogyakarta"[3]. Penelitian mengenai "sistem peminjaman ruangan online (spro) dengan metode uml (unfield modeling language)"[4]. "Aplikasi Sistem Informasi Penyewaan Fasilitas Di Universitas Lancang Kuning Berbasis Online" [5].

\section{LANDASAN TEORI}

\section{A. Model Prototype}

Prototype adalah salah satu metode pengembangan perangkat lunak yang banyak digunakan. Dengan metode Prototyping ini pengembangan dan user dapat saling berintraksi selama proses pembuatan sistem. Sering terjadi seorang pelanggan hanya mendefinisikan secara umum apa yang dibutuhkan, pemrosesan dan data-data apa saja yang dibutuhkan. Sebaliknya disisi pengembang kurang memperhatikan efesiensi algoritma. Kemampuan sistem operasi dan interface yang menghubungkan manusia dengan komputer. Pada prototype model juga kadang-kadang user hanya memberikan beberapa kebutuhan umum software tanpa detail input, proses atau detil output. Di lain waktu mungkin dimana tim pembangun (developer) tidak yakin terhadap 
efisiensi dari algoritma yang digunakan, tingkat adaptasi terhadap sistem operasi atau rancangan form user interface. Ketika situasi seperti ini terjadi model prototype sangat membantu proses pembangunan software[6].

\section{B. Object Oriented Programming (OOP)}

Object oriented programming $(O O P)$ merupakan metode pemrograman yang mengikuti konsep-konsep berorientasi objek yakni encapsulation atau pengkapsulan, inheritance atau pewarisan dan polimorfisme atau keberagaman dalam bentuk lain. Metode ini juga dapat diartikan sebagai cara bagaimana suatu sistem dalam perangkat lunak dibangun melalui pendekatan objek secara otomatis yang didasarkan pada berbagai prinsip pengelolaan kompleksitas yang meliputi rangkaian aktivitas analisis, perancangan, pemograman, dan pengujian berorientasi objek[7].

\section{Unified Modelling Language (UML)}

Unified modelling language (UML) merupakan sebuah bahasa yang menjadi standar dalam industri untuk visualisasi perancangan dan pendukumentasian sistem perangkat lunak. Bahasa pemodelan ini dapat digunakan untuk membuat model dari semua aplikasi perangkat lunak, dimana aplikasi tersebut dapat dijalankan pada perangkat keras sistem operasi dan jaringan apapun, dan dapat ditulis menggunakan bahasa pemograman apapun [8].

\section{Android}

Android adalah sebuah sistem operasi untuk perangkat mobile berbasis linux yang mencakup sistem operasi, middleware dan aplikasi. Android menyediakan platform terbuka bagi para pengembang untuk menciptakan aplikasi mereka. Awalnya, Google Inc. Membeli Android Inc. Yang merupakan pendatang baru yang membuat peranti lunak untuk ponsel/smartphone. Tidak hanya menjadi sistem operasi di smartphone, saat ini Android menjadi pesaing utama dari Apple pada sistem operasi Table PC. Pesatnya pertumbuhan Android selain faktor yang disebutkan di atas adalah karena Android itu sendiri adalah platform yang sangat lengkap baik itu sistem operasinya, Aplikasi dan Tool Pengembangan, Market Aplikasi Android serta dukungan yang sangat tinggi dari komunitas Open Source di dunia, sehingga android terus berkembang pesat baik dari segi teknologi maupun dari segi jumlah device yang ada di dunia[9].

\section{E. $P H P$}

PHP merupakan salah satu bahasa pemrograman berbasis web yang ditulis oleh dan untuk pengembang web. PHP pertama kali dikembangkan oleh Rasmus Lerdorf, seorang pengembang software dan anggota tim apache, dan diliris pada akhir tahun 1994. PHP dikembangkan dengan tujuan awal hanya untuk mencatat pengunjung pada website pribadi Rasmus Lerdorf. Pada rilis keduanya, ditambahkan form intepreter, sebuah tools untuk melakukan penerjemahan perintah SQL. Sejak saat itu, PHP mulai diterima sebagai sebuah bahasa pemrograman baru yang sangat diminati.

PHP adalah pemrograman interpreter yaitu proses penerjemahan baris kode sumber menjadi kode mesin yang dimengerti komputer secara langsung pada saat baris kode dijalankan. PHP disebut sebagai pemrograman server side programming, hal ini dikarenakan seluruh prosesnya dijalankan pada server[10].

\section{F. MySQL}

MySQL merupakan salah satu software untuk database server yang banyak digunakan, MySQL bersifat open source dan menggunakan SQL. MySQL bisa dijalankan di berbagai platform misalnya windows, linux dan lain sebagainya. [11]

\section{MEtodologi PENELITIAN}

\section{A. Model Pengembangan Sistem}

Prototype digunakan sebagai model pengembangan sistem, dimana model ini dapat membantu proses pengembangan dikarenakan model ini dapat dievaluasi dan diubah lagi menyesuaikan kebutuhan. Langkah-langkah yang dilakukan adalah sebagai berikut:

- Pengumpulan Kebutuhan

Tahap pengumpulan kebutuhan dengan menggunakan teknik wawancara, observasi, dan mempelajari pustaka dan penelitian terdahulu untuk mendapatkan kebutuhan dari pihak pengelola peminjaman ruangan.

- Membangun Prototype Setelah mengetahui kebutuhan, dibuat prototype aplikasi yang akan dibangun.

- Evaluasi Prototype

Tahap ini untuk mengetahui apakah dari hasil rancangan prototype apakah sudah sesuai dengan kebutuhan pengguna.

- Pengkodean Sistem

Setelah hasil prototype sesuai dengan kebutuhan, dilanjutkan dengan pembuatan aplikasi.

- Pengujian Sistem

Pengujian sistem dilakukan dengan uji coba aplikasi yang sudah dibangun dengan menggunakan teknik user acceptance testing.

- Evaluasi Sistem

Hasil evaluasi akan menentukan apakah ada perubahan pada aplikasi, kalau ada perubahan maka akan kembali ke tahap pengkodean sistem sampai sistem siap digunakan.

- Penggunaan Sistem

Sistem yang telah sempurna siap untuk digunakan menggantikan proses manual peminjaman ruangan.

\section{B. Metode Pengembangan Sistem}

Dalam penelitian ini, peneliti menggunakan object oriented programming (OOP) sebagai metode pengembangan perangkat lunak. Metode ini dapat memudahkan pengembangan perangkat lunak dengan mengikuti model yang telah ada, model dapat dimodifikasi bahkan dapat dibuat ulang tanpa mengubah kode yang sudah ada, metode pemograman berorientasi objek juga menyediakan struktur modular yang jelas sehingga memudahkan pengembangan dalam 
mendefinisikan tipe data abstrak dan juga metode ini dapat dijalankan di berbagai sistem operasi.

\section{Tools Pengembangan Sistem}

Dalam penelitian ini, peneliti menggunakan unified modelling language (UML) sebagai alat bantu pengembangan sistem. Tools yang digunakan adalah sebagai berikut:

- Use Case Diagram

Use Case Diagram digunakan untuk mendeskripsikan apa saja yang dapat dilakukan oleh sistem.

- Activity Diagram

Activity Diagram menggambarkan sistem secara fungsional atau lebih detail dalam menjelaskan prosesproses secara logika dan fungsi.

- Sequence Diagram

Sequence Diagram menggambarkan aliran data yang ada pada masing-masing tampilan layar aplikasi.

- Class Diagram

Class Diagram digunakan untuk mendesain dan merancang struktur basis data antar objek yang akan digunakan oleh sistem.

\section{HASIL DAN PEMBAHASAN}

\section{A. Analisa Sistem Berjalan}

Pada analisa sistem berjalan akan dijelaskan dengan menggunakan activity diagram, yang akan menjelaskan proses dimana pengguna akan melakukan peminjaman ruangan. Berikut ini adalah activity diagram sistem berjalan:

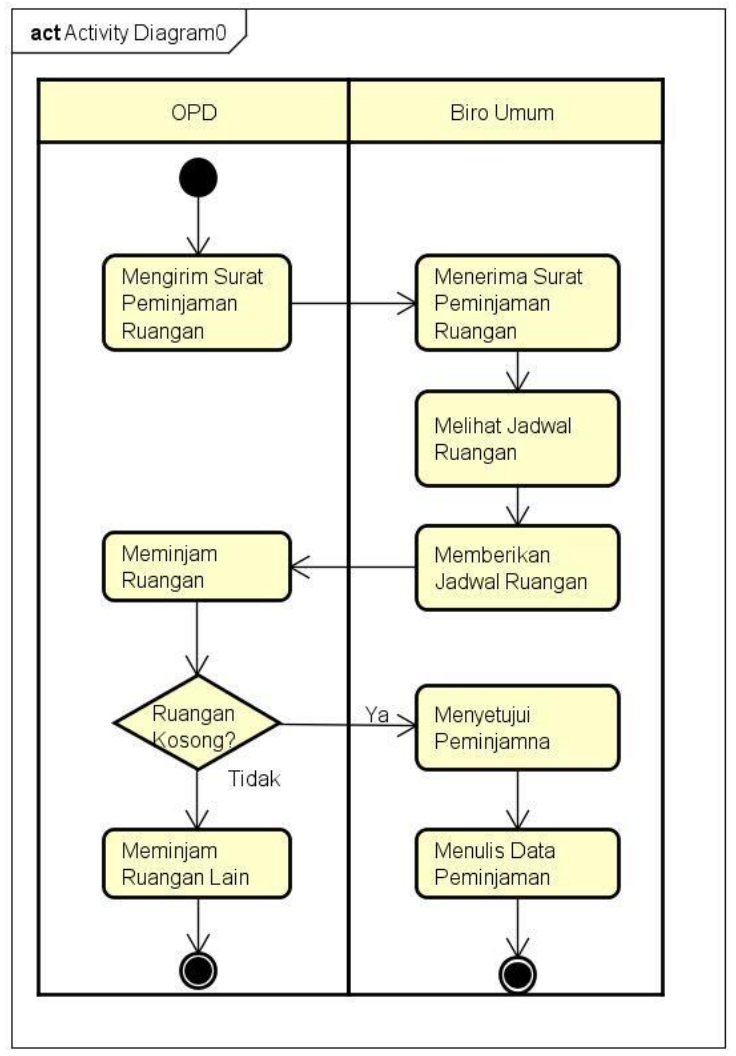

Gambar 1. Activity Diagram Sistem Berjalan
Pada Gambar 1 dijelaskan proses sistem yang sedang berjalan dimana peminjaman ruangan dilakukan masih melalui proses manual, setiap pihak (OPD) yang ingin meminjam ruangan terlebih dulu harus mengajukan surat permohonan peminjaman ruangan, setelah surat permohonan diterima oleh pihak pengelola (Biro Umum), akan diberikan jadwal ruangan yang masih kosong, dan selanjutnya OPD memilih jadwal kapan ruangan akan dipinjam, jika ruangan kosong pada jadwal yang dipilih, maka Biro Umum akan menyetujui peminjaman ruangan dengan menuliskan data peminjaman ruangan.

\section{B. Rancangan Sistem}

Dengan menggunakan aplikasi web sebagai server dan android sebagai client, peneliti akan membangun suatu aplikasi peminjaman ruangan rapat yang akan berfungsi untuk melakukan peminjaman yang dipilih oleh pengguna. Pertama administrator akan memasukkan data, data ruangan, dan data masing-masing data kedalam web server, kemudian user dapat menggunakan aplikasi android untuk menampilkan data-data sesuai dengan yang ada di web server. Pengguna dapat memilih ruangan lalu melakukan proses prminjaman. Data Ruangan yang dipilih kemudian akan dikirimkan ke web server. Di web server data akan di proses. Kemudian hasil dari proses ini akan dikirimkan kembali ke aplikasi android pengguna berupa konfirmasi peminjaman ruangan.

\section{1) Use Case Diagram Sistem Usulan Server}

Berikut ini adalah uce case diagram sistem usulan pada server yang digunakan dalam pembuatan aplikasi:

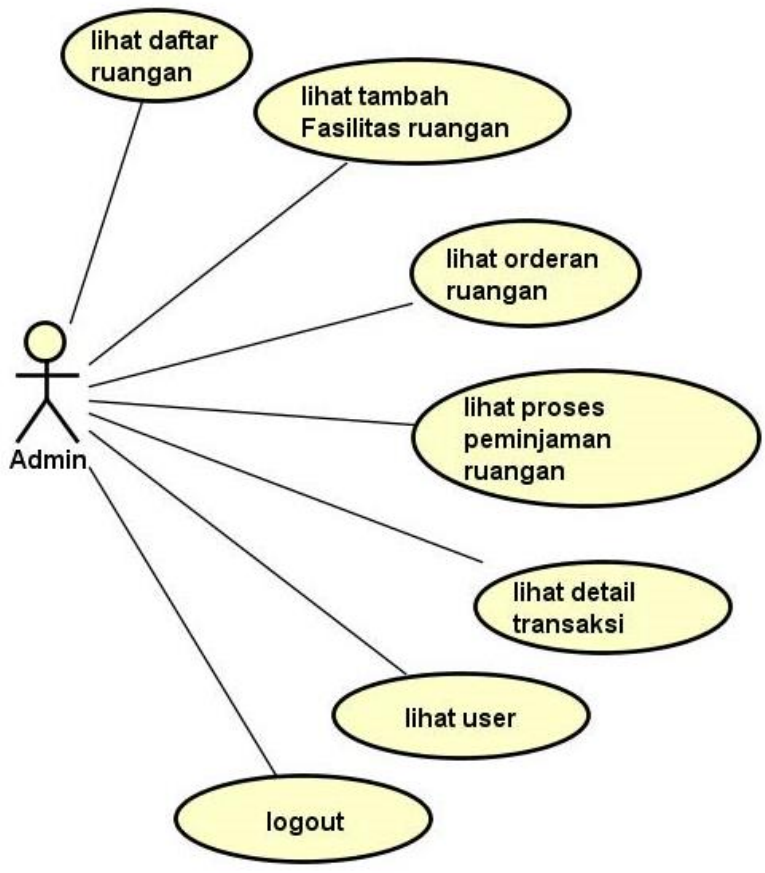

Gambar 2. Use Case Diagram Sistem Usulan Server 
Gambar 2 menjelaskan pada aplikasi server (aplikasi yang digunakan pihak pengelola) mempunyai akses untuk menambah daftar ruangan, menambah fasilitas ruangan, melihat transaksi peminjaman ruangan, melihat proses peminjaman ruangan, melihat detail transaksi peminjaman, melhat daftar pengguna.

\section{2) Use Case Diagram Sistem Usulan User}

Berikut ini adalah use case diagram sistem usulan pada user yang digunakan dalam pembuatan aplikasi:

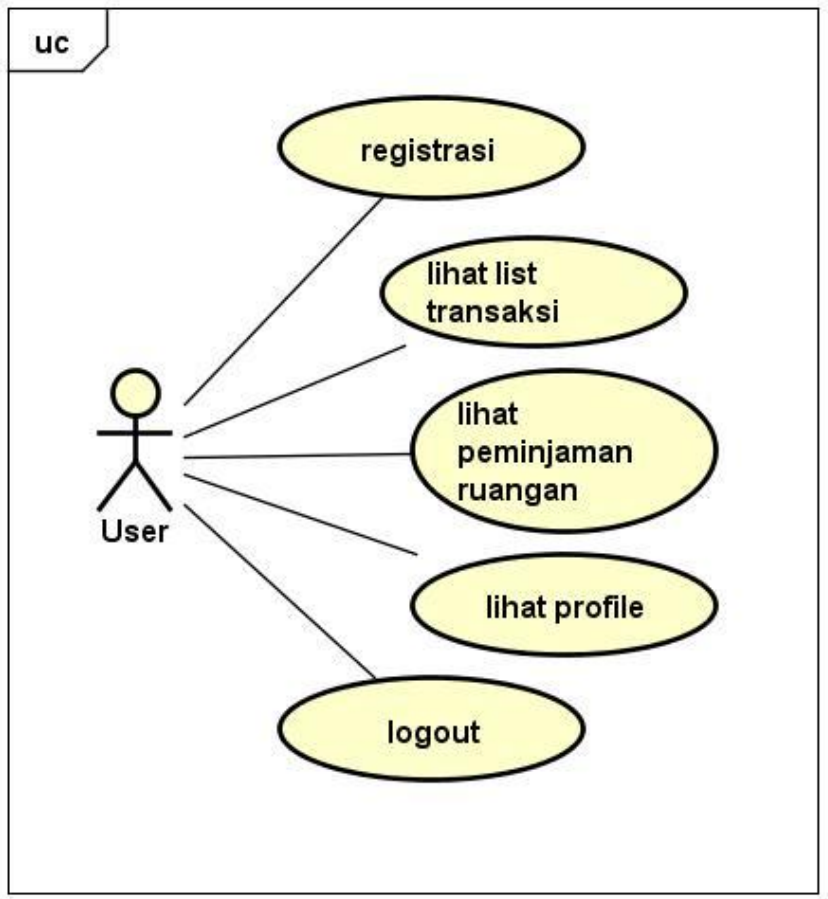

Gambar 3. Use Case Diagram Sistem Usulan User

Gambar 3 menjelaskan aplikasi client (aplikasi yang akan digunakan oleh pihak yang akan meminjam ruangan) mempunyai akses untuk registrasi, melihat daftar transaksi, meminjam ruangan, melihat profil.

\section{3) Activity Diagram Peminjaman Ruangan}

Pada gambar dibawah dijelaskan proses untuk melihat form data ruangan. Pengguna membuka menu ruangan, kemudian memilih ruangan yang ingin di sewakan. Setelah itu sistem akan mengambil data ruangan dari server, lalu menampilkan form data ruangan. Pengguna dapat meng-input waktu sewa yang diinginkan, setelah itu klik tombol add to cart, sistem akan mengkonfirmasi ke database.

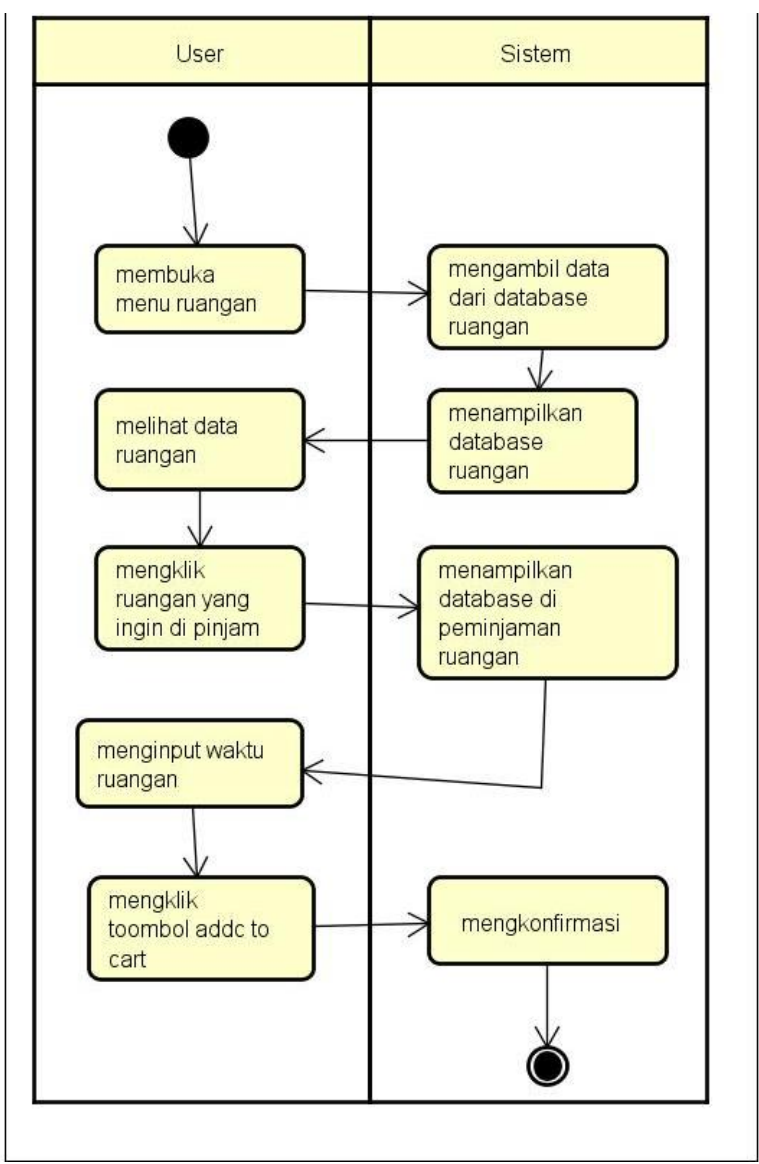

Gambar 4. Activity Diagram Peminjaman Ruangan

Gambar 4 menjelaskan proses peminjaman ruangan yang dilakukan melalui aplikasi client dimana pengguna membuka menu ruangan dan akan tampil daftar ruangan yang tersedia, dan melakukan peminjaman ruangan dengan menginput tanggal dan waktu peminjaman, selanjutnya proses peminjaman akan diproses oleh sistem.

\section{4) Sequence Diagram Proses Peminjaman Ruangan}

Pada gambar 4.31 dijelaskan bahwa pengguna memilih form proses peminjaman ruangan, kemudian mengklik detail peminjaman, admin menekan tonbol selesai untuk mengkonfirmasikan bahwa setatus sewa ruangan telah berakhir.

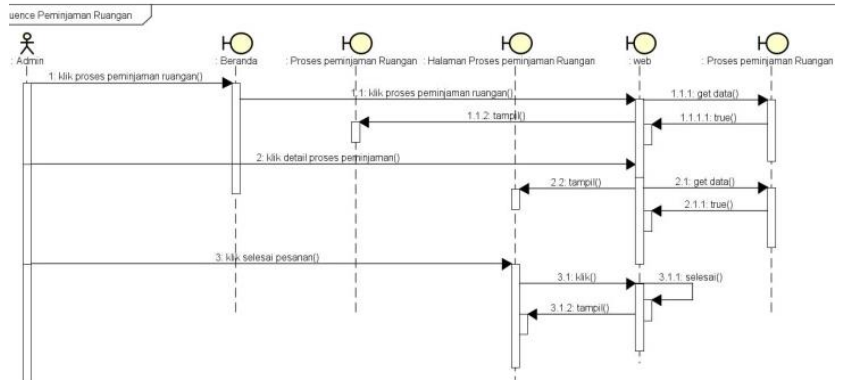

Gambar 5. Sequence Diagram Proses Peminjaman Ruangan 


\section{5) Class Diagram Sistem Usulan}

Class Diagram digunakan untuk menampilkan struktur sistem dari kelas-kelas yang ada pada system peminjaman ruangan. Model class diagram dapat dilihat pada gambar dibawah ini.

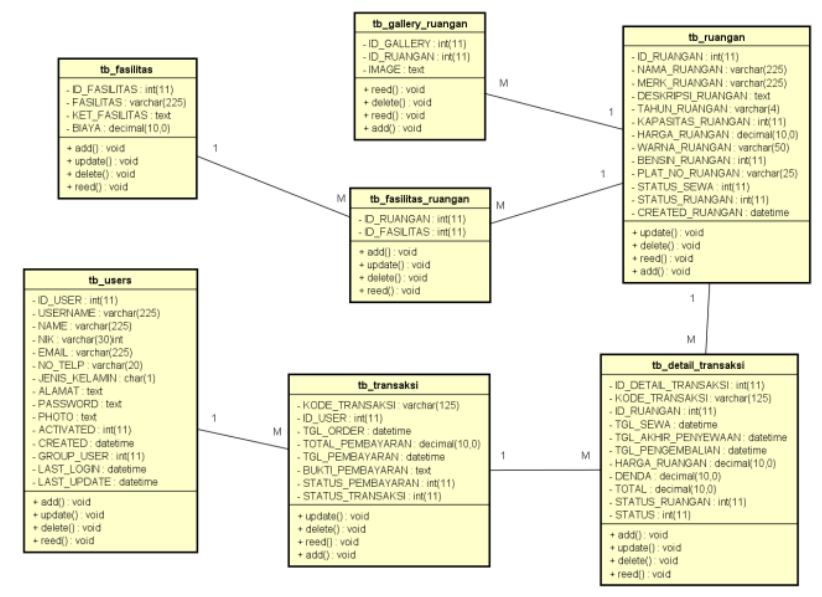

Gambar 6. Class Diagram Sistem Usulan

Gambar 6 menjelaskan spesifikasi tabel pada basis data yang akan digunakan dimana terdapat 7 tabel untuk aplikasi peminjaman ruangan.

\section{Rancangan Layar}

\section{1) Rancangan layar login}

Pada gambar 7 menampilkan rancangan layar login pada aplikasi android, untuk menginput username dan password pengguna.

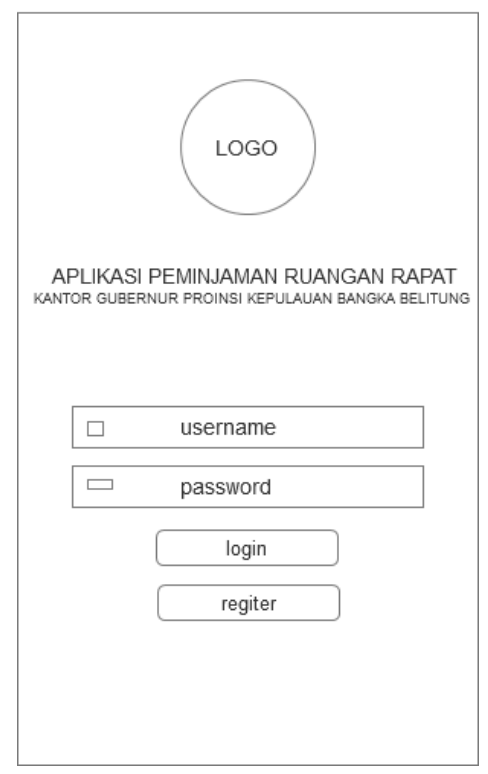

Gambar 7. Rancangan layar login

\section{2) Rancangan layar menu utama pengguna}

Pada gambar 8 menampilkan rancangan layar menu utama pengguna pada aplikasi android

\begin{tabular}{|l|}
\hline bagckround \\
nama \\
$\square$ List Transaksi \\
$\square$ Ruangan \\
\\
$\square$ Lihat Profil \\
$\square$ Logout \\
\hline
\end{tabular}

Gambar 8. Rancangan layar menu utama pengguna

3) Rancangan layar data ruangan

Pada gambar 9 menampilkan rancangan layar data ruangan yang berfungsi untuk menampilkan data ruangan dan dapat dilakukan untuk memesan ruangan.

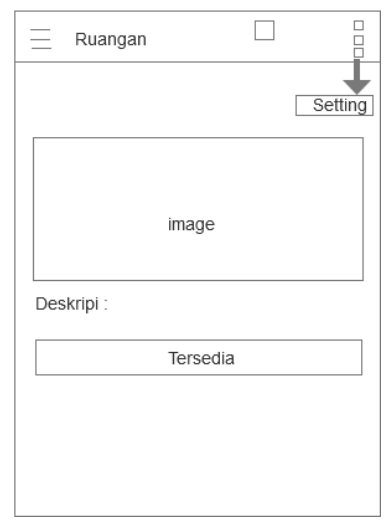

Gambar 9. Rancangan layar data ruangan

\section{4) Rancangan layar form daftar ruangan}

Pada gambar 10 menampilkan form halaman ruangan yang berisi tentang data peminjaman ruangan.

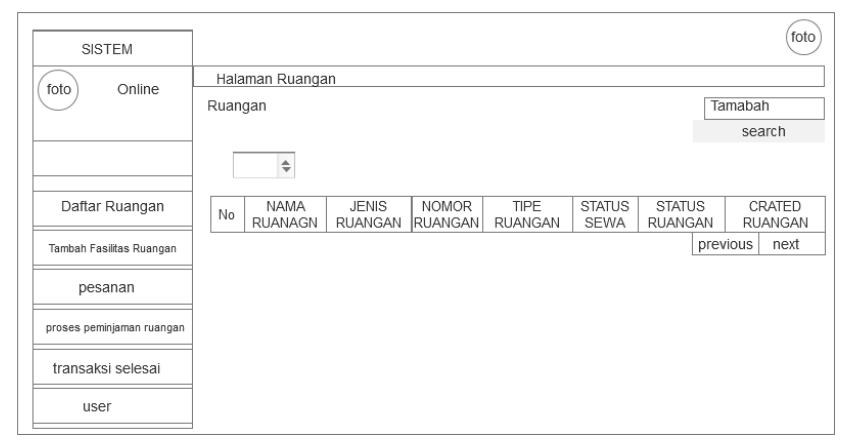

Gambar 10. Rancangan layar daftar ruangan 


\section{5) Rancangan layar form fasilitas ruangan}

Pada gambar 11 menampilkan form halaman fasilitas ruangan yang berfungsi untuk menampilkan data fasilitas ruangan.

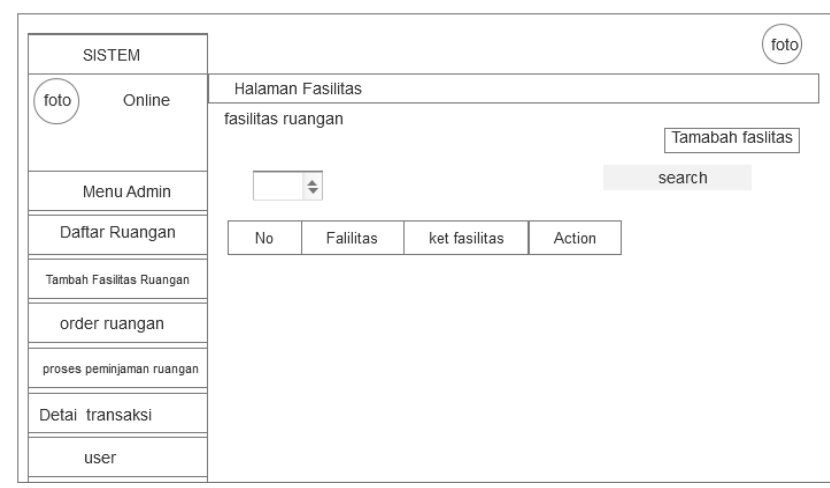

Gambar 11. Rancangan layar form fasilitas ruangan

6) Rancangan layar form proses peminjaman ruangan

Pada gambar 12 menampilkan rancangan layar halaman peminjaman ruangan yang berfungsi untuk konfirmasi selesainya peminjaman.

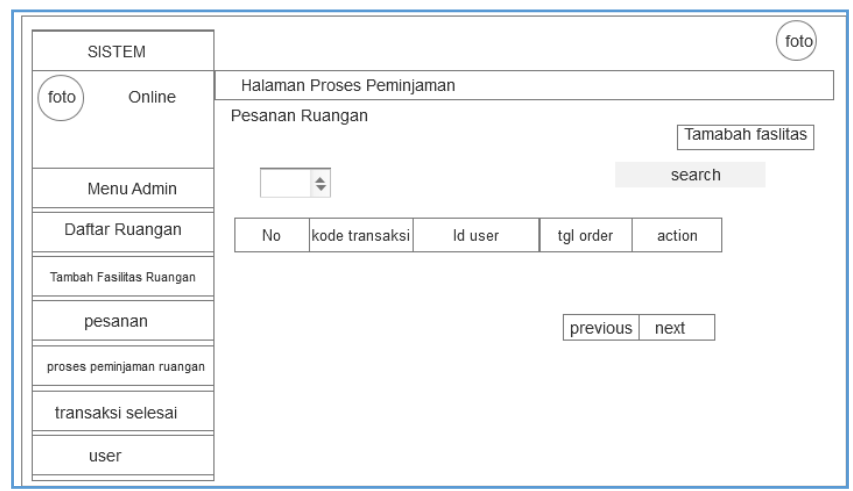

Gambar 12. Rancangan layar form proses peminjaman

\section{7) Rancangan layar form detail transaksi}

Pada gambar 13 menampilkan rancangan layar halaman transaksi selesai yang berfungsi untuk melihat detail transaksi yang telah selesai.

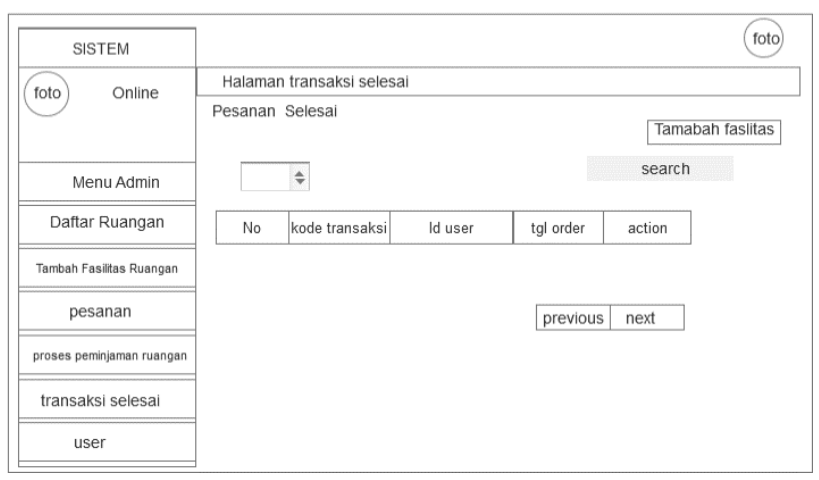

Gambar 13. Rancangan layar form detail transaksi

\section{Implementasi}

\section{1) Tampilan layar login}

Gambar 14 menampilkan tampilan layar login pada aplikasi android. Pengguna yang sudah mempunyai akun bisa login dengan memasukkan username dan password, jika belum mempunyai akun, pengguna bisa klik Register untuk mengisi form pendaftaran.

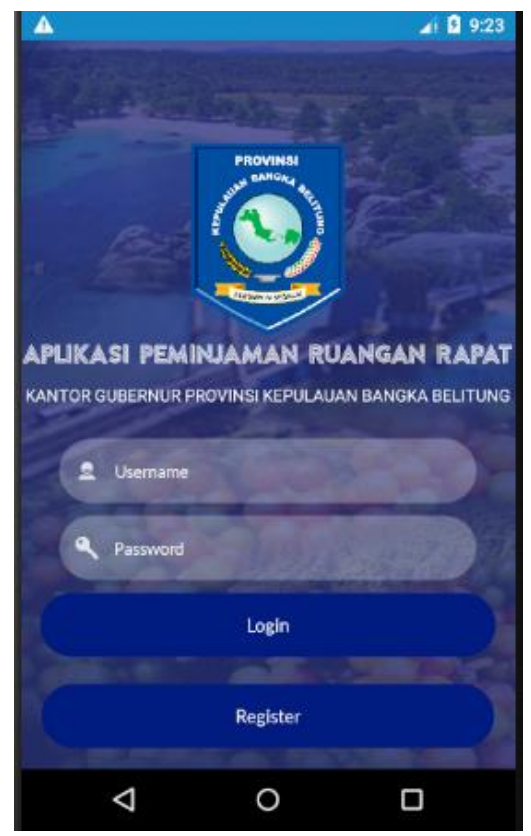

Gambar 14. Tampilan layar login

\section{2) Tampilan layar menu utama pengguna}

Gambar 15 menampilkan form menu utama pada aplikasi android yang berfungsi untuk menampilkan list transaksi, ruangan, lihat profil, dan logout.

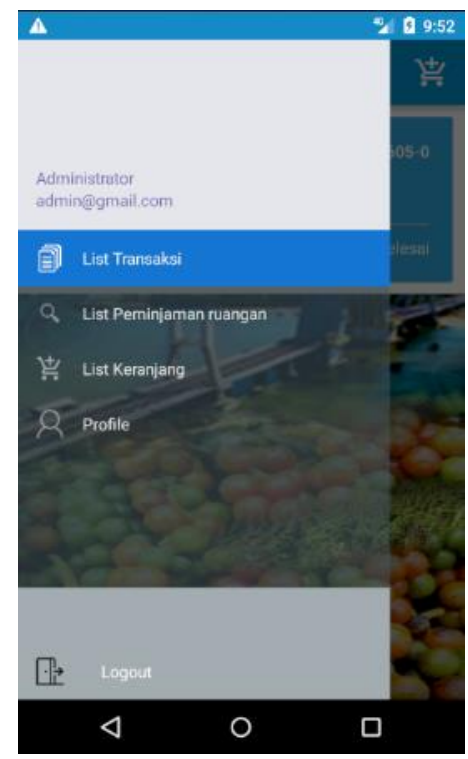

Gambar 15. Tampilan layar menu utama pengguna

ISSN $: 2301-7988$

E-ISSN : 2581-0588

DOI $\quad: 10.32736 /$ sisfokom.v8i2.688 


\section{3) Tampilan layar data ruangan}

Gambar 16 menampilkan form ruangan yang berisi data-data ruangan yang dapat dipinjam. Jika ruangan tidak tersedia maka tampilkan tombol tersedia tidak bisa diklik. Pada tampilan menu ini, akan dijelaskan nama ruangan dan fasilitas ruangan yang meliputi kapasitas ruangan, warna dinding, dan tahun ruangan dibuat.

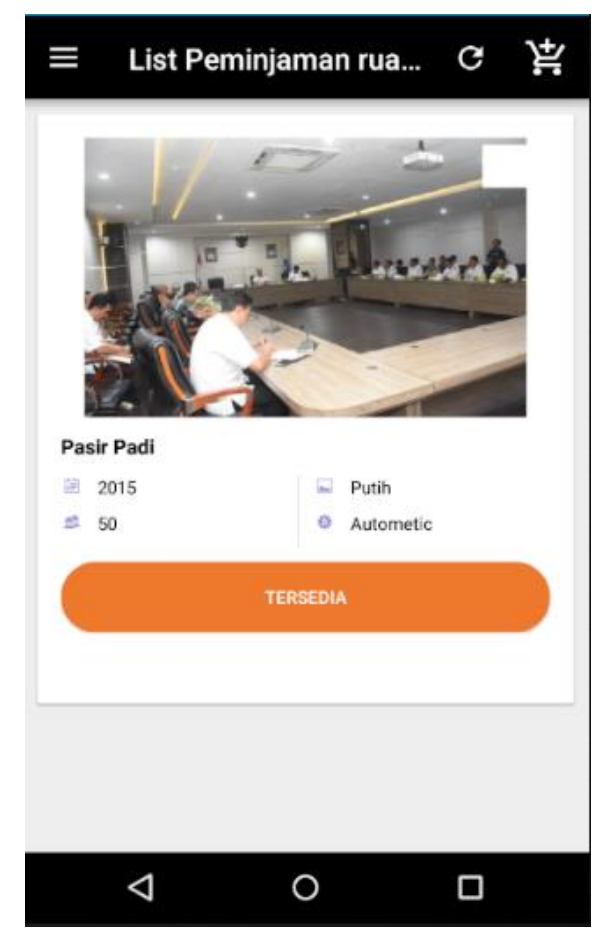

Gambar 16. Tampilan layar data ruangan

\section{4) Tampilan layar form daftar ruangan}

Gambar 17 menampilkan form halaman ruangan yang berisi daftar ruangan yang digunakan pihak pengelola untuk menambah, mengubah, dan menghapus daftar ruangan yang ada.

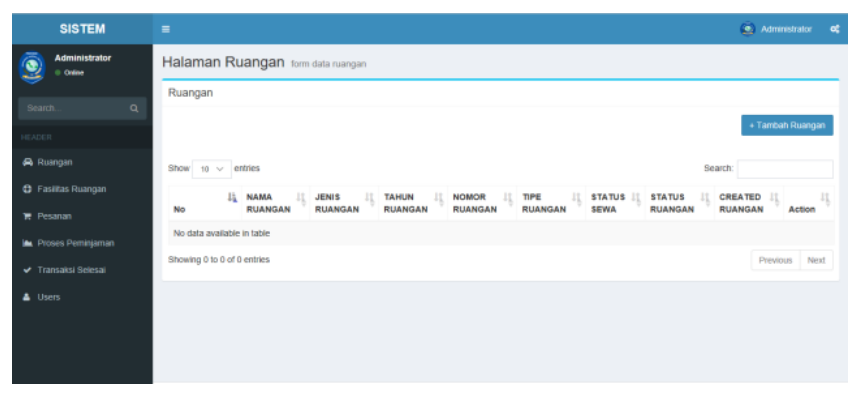

Gambar 17. Tampilan layar form daftar ruangan

\section{5) Tampilan form tambah fasilitas ruangan}

Gambar 18 menampilkan form tambah fasilitas yang berfungsi untuk menambah, mengubah dan menghapus fasilitas ruangan yang digunakan pihak pengelola terkait dengan daftar ruangan yang tersedia.

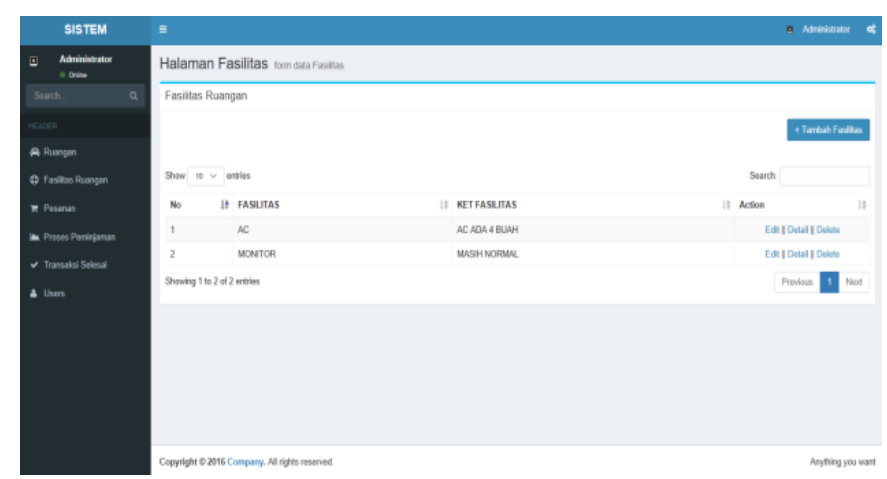

Gambar 18. Tampilan layar tambah fasilitas

6) Tampilan layar form proses peminjaman ruangan

Gambar 19 menampilkan form proses peminjaman ruangan yang berfungsi untuk menampilkan detail data proses ruangan. Di proses ruangan ini juga bisa mengkonfirmasi proses selesainya peminjaman ruangan.

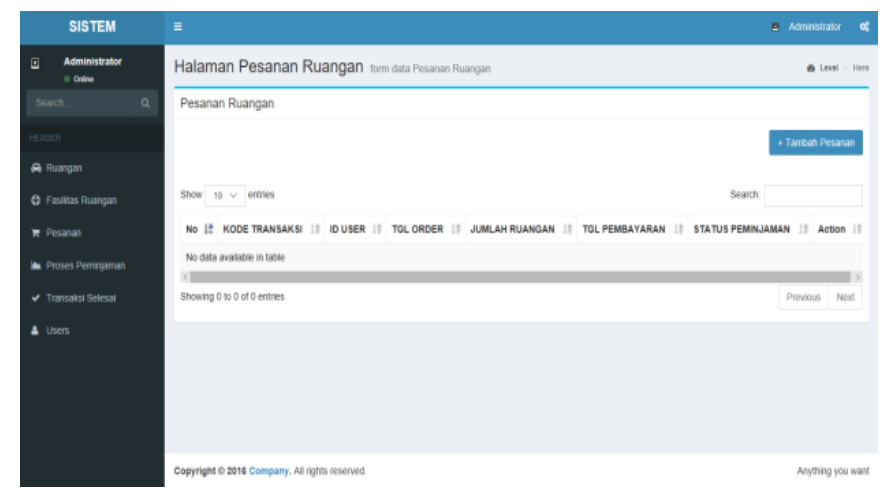

Gambar 19. Tampilan layar proses peminjaman

7) Tampilan layar form detail transaksi

Gambar 20 digunakan oleh pihak pengelola untuk menampilkan detail transaksi yang berfungsi melihat halaman transaksi pemesanan ruangan meliputi siapa yang meminjam ruangan, kapan peminjaman ruangan yang dilakukan. Dari tampilan ini juga dapat memberikan laporan yang dapat dicetak untuk selanjutnya digunakan.

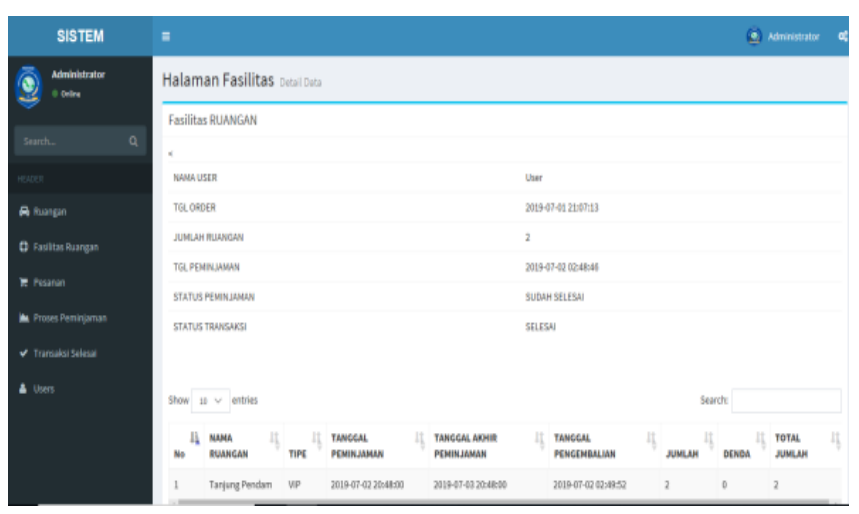

Gambar 20. Tampilan layar detail transaksi 


\section{E. Pengujian Black Box}

TABEL 1. PENGUJIAN APLIKASI ANDROID

\begin{tabular}{|c|c|c|}
\hline Fitur yang diuji & $\begin{array}{c}\text { Hasil yang } \\
\text { Diharapkan }\end{array}$ & Hasil \\
\hline Login & Masuk ke form login & Sesuai \\
\hline Menu Splash & $\begin{array}{c}\text { Masuk ke form menu } \\
\text { utama }\end{array}$ & Sesuai \\
\hline Pilih ruangan & $\begin{array}{c}\text { Masuk ke form daftar } \\
\text { ruangan }\end{array}$ & Sesuai \\
\hline Pilih list transaksi & $\begin{array}{c}\text { Masuk ke form list } \\
\text { transaksi }\end{array}$ & Sesuai \\
\hline Pilih lihat profile & $\begin{array}{c}\text { Masuk ke form lihat } \\
\text { profile }\end{array}$ & Sesuai \\
\hline $\begin{array}{c}\text { Pilih keranjang } \\
\text { Pasuk ke form list } \\
\text { ruangan }\end{array}$ & Sesuai \\
\hline ruangan & $\begin{array}{c}\text { Masuk ke form input } \\
\text { data pemesanan } \\
\text { ruangan }\end{array}$ & Sesuai \\
\hline Pilih menu logout & Masuk ke form logout & Sesuai \\
\hline
\end{tabular}

\section{PENUTUP}

Berdasarkan hasil penelitian yang telah penulis lakukan, maka didapati kesimpulan bahwa aplikasi ini dirancang dengan model prototype sebagai model pengembangan perangkat lunak dimana model ini dapat membantu proses pengembangan aplikasi ini. Dan juga aplikasi peminjaman ruangan berbasis android ini mampu memberi kemudahan terhadap pengguna untuk melakukan transaksi peminjaman ruangan serta aplikasi ini juga dapat mempermudah pengelola untuk mengetahui laporan peminjaman ruangan.

\section{REFERENSI}

[1] A. Fitri, "Aplikasi Pengelolaan dan Peminjaman Ruangan di Fakultas Ilmu Terapan”, e-Proceeding of Applied Science, vol. 3, no. 02, 2017.

[2] T. Larasai, "Sistem Informasi Peminjaman Barang Fakultas MIPA UNS", Jurnal Magister Teknik Informatika Universitas Sebelas Maret Surakarta, vol. 13, no. 2, pp. 11-34, 2017.

[3] Rosnadewi, M. Devinta., "Pengembangan Aplikasi Peminjaman Ruangan SUBAG Umum Kepengawaian dan Perlengkapan (UKP) FMIPA UNY", unpublished.

[4] A. A. Rak P.W.A, M. H. Maulana, C. D. Andini, F. Nadziroh, "Sistem Peminjaman Ruangan Online (SPRO) dengan Metode UML (Unfield Modeling Language)", Jurnal Teknologi dan Terapan Bisnis [JTTB], vol. 1 , no. $1,2018$.

[5] N. Nasutio, M. A. Hasan, "Apliaksi Sistem Penyiwaan Fasilitas Di Universitas Lancang Kuning Berbasis Online”, Jurnal Inovtek PolbengSeri Informatika vol. 2, no. 2, 2017.

[6] A. P. Afgan, A. P. Yuli, A. Nia, "Pengembangan Web E-Commerce Bojana Sari Menggunakan Metode Prototype", Jurnal Tugas Akhir Fakultas Rekayasa Industri, vol. 2, no. 1, 2015

[7] W. Kadek, "Analisa Konsep Object Oriented Pada Bahasa Pemprograman PHP”, Jurnal AMIK Bina Sarana Informatika, Jakarta Selatan, 2015.

[8] A. S. Rosa, M. Salahudin, "Rekayasa Perangkat Lunak Terstruktur dan Beroriantasi Objek", Informatika, Bandung, 2015.

[9] N. P. Khojimah, “Aplikasi Jaket Kulit Berbasis Android Dengan Gis di Kota Bandar Lampung”, Ilmu Komputer Fakultas Matematika Teknik dan Ilmu Komputer, Universitas Komputer Indonesia, Bandung, 2014.

[10] N. H. Marzuq, "Sistem Informasi Single User Penerimaan Pesrta Didik Baru Berbasis PHP di Sekolah Menengah Pertaa Islamiyah Widodaren Ngawi”, Fakultas Teknik Informatika, Univ. Samawa, Sumbawa, 2013.

[11] W. Fauziah, "Penerapan Metode Simle Additive Weighting dalam Sistem Pendukung Keputusan Kelayakan Laboratorium Komputer SMP dan SMA Negeri Untuk Unit Pelaksana Teknis Dinas Pendidikan Kecamatan Sukorejo", Teknik Elektro, Fakultas Teknik Universitas Negeri Semarang, 2015. 